DOI: 10.14526/2070-4798-2020-15-1-24-28

\title{
Motives change, which stimulate 9-11 year-old children to attend training lessons, during platform diving
}

\author{
Evgeniya A. Raspopova* \\ Russian State University of Physical Culture, Sport, Youth and Tourism \\ Moscow, Russia \\ ORCID: oooo-Ooo2-1129-4492, raspopova48@mail.ru*
}

\begin{abstract}
The article presents the results of yearly observations over young athletes. They go in for diving at a sports school for children and teen-agers. The received results show that among most children motivation increases during the training lessons. Children receive more information about the kind of sport. The strongest athletes want to improve their level of achievements. Materials. The article is about the motives change among young divers within the year of training period. Research materials. Information sources analysis and summarizing, questionnaire survey, methods of statistical data handling. Results. It was revealed that $20 \%$ of children stopped going to diving as they couldn't master the jumps because of fear. The level of their motivation, received during the first research, was considerably lower, than among children, who continued their training lessons. Most young athletes, who continued their lessons, want to be like well-known divers, are satisfied with their coach, want to achieve high results and like to take part in competitions. Conclusion. This article is about the peculiarities of the motives change. They stimulate 9-11 year-old children to go in for diving. It was revealed that the main motives, which stimulate young athletes to overcome great training loads, are the following: "The desire to achieve high results", "To be like a famous athlete".
\end{abstract}

Keywords: motives, diving, 9-11 year-old children, competitions, sport.

For citation: Evgeniya A. Raspopova*. Motives change, which stimulate 9-11 year-old children to attend training lessons, during platform diving. Russian Journal of Physical Education and Sport. 2020; 15(1): 2124. DOI: $10.14526 / 2070-4798-2020-15-1-24-28$

\section{INTRODUCTION}

In sports activity the main motives have social meaning and importance and are considered through the definite interests of each personality [1]. This concept is called the theory of a gradual stage-by-stage motives formation. According to this theory it is necessary to look for the definite ways of psychological influence on a person and gradually form his consciousness [2,3,4].

The work of the coaches in diving is connected with motives upbringing and formation for further sportsmanship improvement in athletes. Interests absence leads to the fact that people stop going in for this kind of sport and choose another kind of sport [5]. For children, who don't have inclination for diving, it can be a positive moment [6]. Such children can realize themselves in other kind of activity or sport. At the age of 9-11children, who went through the initial selection and have the definite combination of qualities for further development, go in for sports schools for children and teen-agers. As the practice shows, the main selection of young athletes happens at the stages of mastering backward jump with repeated rotations. The main reason of selection is fear of losing orientation during the flight and water impact. In order to overcome the sense of fear a coach should use all his pedagogical mastery, in order to make a young athlete fulfill the jump. We considered the changes of motives. They stimulate 9-11 year-old children to continue diving lessons.

The aim of the research was to study the dynamics of motives during training lessons during the age period: 9-11 years old.

The following objective was set - to reveal motives change. They stimulate 9-11 year-old 
children to go in for diving.

\section{MATERIALS AND METHODS}

Information sources analysis and summarizing, questionnaire survey among young athletes. They go in for diving to sports school for children and teen-agers in Moscow, in order to reveal the motives, which stimulate to go in for diving; methods of mathematical statistics.

At the first stage of experiment we realized a questionnaire survey among 9-11 year-old students of sports school for children and teen-agers of the Olympic reserve in diving in Moscow in order to reveal the motives, which stimulate them to go in for diving. The experience of going in for diving among the respondents was 3-4 years, sports qualification - from the $1^{\text {st }}$ youth till the $2^{\text {nd }}$ category.

100 girls and boys at the age of 9-11 took part in the research. They went in for diving at sports school for children and teen-agers in Moscow since 2005 till 2015. The questionnaire was held every year during the competitions of sports school for children and teen-agers.

At the second stage of experiment we realized a questionnaire survey among 9-11 yearold students of sports school for children and teenagers of the Olympic reserve in diving in Moscow. The experience of going in for diving among the respondents was 3-4 years, sports qualification from the $1^{\text {st }}$ youth till the $3^{\text {rd }}$ adult category.

In a year we held additional questionnaire survey among children, who took part in the first research, in order to reveal changes in motives. They stimulate children continue their training diving lessons. Within a year most children improved their qualification at least for one category.

As a result of the first questionnaire survey we defined the main motives. They stimulate children go in for diving at sports school for children and teen-agers of the Olympic reserve (Table 1).

During the questionnaire survey we offered to range the motives according to the degree of importance. Many respondents mentioned more than one motive as important ones. As a result of the questionnaire survey it was revealed that the most important motives for the lessons beginning were the following: "Desire to achieve high sports results", "Health improvement", "It is fashionable to go in for sports". These answers gave $80 \%$ of children, $50 \%$ of children "want to be like famous athletes".

The received answers mean that the main motive for diving training lessons beginning at a sports school for children and teen-agers of the Olympic reserve is the desire to improve fitness, become like the leading athlete, as in modern society it is modern to go in for sports.

$40 \%$ and $43 \%$ of the respondents mentioned that they liked to spend free time at the training lessons and swim after the training and paly. Almost 30\% of children go in for diving as they like their coach or parents make them or they think training lessons are the place of meeting new friends.

Table 1 - The results of the first questionnaire survey for the motives revelation, which stimulate 9-11 yearold children to go in for diving (6o people)

\begin{tabular}{|c|c|c|}
\hline № & Motive & $\begin{array}{c}\text { \% of children, who } \\
\text { mentioned this motive as } \\
\text { important one }\end{array}$ \\
\hline 1. & To achieve high results. & $80 \%$ \\
\hline 2. & Health improvement. & $80 \%$ \\
\hline 3. & It is fashionable to go in for sports. & $80 \%$ \\
\hline 4. & Want to be like a famous athlete. & $50 \%$ \\
\hline 5. & Like to swim after the training. & $43 \%$ \\
\hline 6. & Like to spend my free time this way. & $40 \%$ \\
\hline 7. & I like the coach. & $26 \%$ \\
\hline 8. & To find friends. & $26 \%$ \\
\hline 9. & Parent make me. & $30 \%$ \\
\hline
\end{tabular}


The questionnaire survey was held every year. We tried to include new 9 year-old students into the questionnaire survey and students, who answered the questions last year. It should be noted that almost $20 \%$ of children, who were asked during the first survey, finished their diving lessons within a year because of different reasons. After the talk with the coaches it was clear that these children didn't correspond with the demands of sports readiness of this age group, were afraid to fulfill difficult for their age jumps. Some children stopped going in for the training lessons because of social reasons (moving to another place of living, no person to go to the training lessons with a child and others).

The results of the additional questionnaire survey among young athletes with the results, received at the beginning of the experiment, prove the change of motives, which stimulate children to go in for the training lessons (Table 2). Answering the question "Would you like to become a famous athlete or be like some famous athlete?" most respondents mentioned that they want to be like famous divers. At the same time, young athletes, who had a positive answer, didn't change their minds and the athletes, who didn't want to be like famous divers, changed their minds. It shows that during the year of training lessons children gained the desire to achieve higher results.

Answering the question "Would you like to find friends?" most athletes gave negative answer. However, they mentioned that at a sports school for children and teen-agers of the Olympic reserve they have a lot of friends. Thus, a negative answer can be considered as the absence of the necessity to find new friends, as they have a lot of friends at a sports school.

Table 2 - motives changes, which stimulate to go in for diving lessons among athletes, who continue lessons at a sports school for children and teen-agers of the Olympic reserve (40 people)

\begin{tabular}{|l|c|c|}
\hline \multicolumn{1}{|c|}{ QUESTIONS } & $\begin{array}{c}\text { The answer changed } \\
\text { and became positive }\end{array}$ & $\begin{array}{c}\text { The answer } \\
\text { didn't change }\end{array}$ \\
\hline $\begin{array}{l}\text { Would you like to become a famous athlete or be like some } \\
\text { famous athlete? }\end{array}$ & No - 57,7\% & $42,3 \%$ \\
\hline Would you like to find new friends? & No - 65,4\% & Yes - 34,6\% \\
\hline Do you like to play after the training lesson? & Yes - 30,8\% & Yes - 61,5\% \\
\hline Do you like your coach? & Yes - $61,5 \%$ & $38,5 \%$ \\
\hline Do you like to take part in the competitions? &
\end{tabular}

Answering the question "Do you like to play after the training lesson?” most respondents changed their answers from positive (Yes, I like) to negative one (No). Initially they liked to play and swim after the training lesson and now it was not an important motive for them. Great loads during the training lesson didn't leave strength for games.

Answering the question "Do you like your coach?" $92,3 \%$ of respondents gave a positive answer, although answering the question "Does your coach screams at you?" $84,4 \%$ of respondents gave a positive answer "Yes".

It is true, very often coaches scream at their students in order to increase the emotional level of the lesson, which as a result has a positive influence on the attitude of athletes to lessons. Emotional atmosphere proves the interest of a coach in students and the desire to make them achieve the definite results. Most students understand it.

Answering the question "Do you like to take part in the competitions?" 100\% of athletes, who continue going in for diving, in a year gave a positive answer, although before it positive answer was given only by $42,3 \%$ of the respondents. We can suppose that young athletes, who continue going in for sports, gained the desire to achieve high results and the sense of rivalry.

\section{CONCLUSION}

The held research work showed that when children are 9-11 years-old their sports character is formed, they gain the desire to train and desire to compete. Young athletes start to understand the role of a coach in their training. The age period of 9-11 is the key period when selecting athletes for further improved training. 


\section{REFERENCES}

1. Galperin P.Ya. Vvedenie $v$ psihologiyu [Introduction into psychology]. Moscow: Book house, University. 2005: 330 [In Russ.].

2. Gorokhovskiy L.Z. Podgotovka prygunov $v$ vodu [Training divers]. Moscow: Physical culture and sport. 1980: 176 [In Russ.].

3. Ilin E.P. Motivatsiya I motivy [Motivation and motives]. Saint-Petersburg: Piter. 2008: 508 [In Russ.].

4. Piloyan R.A. Motivatsiya sportivnoj deyatel'nosti [Motivation in sports activity]. Moscow: Physical culture and sport. 2005: 104 [In Russ.].

5. Raspopova E.A. Pryzhki $v$ vodu: uchebnik dlya vuzov fizicheskoj kul'tury [Diving: Textbook for physical culture higher educational establishments]. M.: Physical culture, education, science. 2000: 302 [In Russ.]

6. Evgeniya A. Raspopova, Yuliya A. Postolnik. Comparative analysis of dominant motives inducing students fromdifferent higher educational establishments to go in for physicalculture lessons. Pedagogiko-psihologicheskie I medicobiologicheskie problemy fizicheskoj kul'tury I sporta = The Russian Journal of Physical Education and Sport. 2018; 13(1): 125-132. DOI 10/14526/01_2018_291 [In Russ., In Engl.].

7. Evgeniya A. Raspopova, Olga A. Khorosheva. Health state estimation of simmersveterans before the important start. Pedagogiko- psihologicheskie I medico-biologicheskie problemy fizicheskoj kul'tury I sporta = The Russian Journal of Physical Education and Sport. 2018; 13(1): 193198. DOI: 10/14526/01_2018_291 [In Russ., In Engl.].

8. Bishop D. Warm up II: Performance changes following active warm up and how to structure the warm up. Sports Medicine. 2003; 33: 483-498.

9. Bradley P.S., Olsen P.D., Portas M.D. The effect of static, ballistic, and proprioceptive neuromuscular facilitation stretching on vertical jump performance. Journal of Strength and Conditioning Research. 2007; 21: 223-226.

10. Brandenburg J., Pitney W., Luebbers P., Veera A., Czajka A. Time course of changes in vertical-jumping ability after static stretching. International journal of Sports Physiology and Performance. 2007; 2: 170-181.

11. Faigenbaum A.D., Bellucci M., Bernieri A., Bakker A., Hoorens K. Acute effects of different warm-up protocols on fitness performance in children. Journal of Strength and Conditioning Research. 2005; 271: R1251-R1255.

12. McNeal J., Sands W. Acute static stretching reduces lower extremity power in trained children. Paediatric Exercise Sciences. 2003; 15: 139-145.

13. Nelson A.G., Driscoll N.M., Landin D.K., Young M.A., Schexnayder I.C. Acute effects of passive muscle stretching on sprint performance. Journal of Sports Sciences. 2005; 23: 449-455.

Submitted: 21.02.2020

\section{Author's information:}

EvgeniyaA. Raspopova-Doctor of Pedagogics, Professor, Russian State University of PhysicalCulture, Sport, Youth and Tourism, 105122, Russia, Moscow, Sirenevyi blvd., House 4, e-mail: raspopova48@ $\underline{\text { mail.ru }}$ 